intrusive masses varying much in composition, are all circumstances favourable to the development of mineral deposits in them. Gold is the only mineral that has been found in payable quantities in these ranges, and that only in a very limited area of about fifty square miles, situated seventy to eighty miles E.N.E. of Alice Springs, on the Arltunga or Paddy's Hole goldfield. Although, as just stated, gold in payable quantities has been found on the above-mentioned goldfield, yet alluvial gold in small quantities has been found also near Winnecke's Depôt, Bald Hill, and in some of the gullies in the Georgina Range.

The most important auriferous quartz reefs have a prevailing due north and south trend, and their gold contents show a remarkable uniformity. The country-rock includes metamorphic gneisses and mica schists, intruded by eruptive dykes. Where not absolutely vertical the underlay is almost without exception to the west, and varies from $5^{\circ}$ to $10^{\circ}$. The outcrops of these reefs, which are not, as a rule, traceable for any great distance, vary in width from four inches to two feet six inches, while at the bottom of trenches and shafts the width varies from three inches up to four feet six inches. Taking the average of ten reefs, the width at the surface was found to be twelve inches, while at an average depth of twenty-one feet it was fifteen inches. Gold is contained not only in the veinstone, but occasionally and in a less degree in the selvage also, on one or both sides of the reef. In nearly all the reefs the gold is associated with gossary quartz, some of the best results being obtained from a spongy siliceous matrix, which crumbles easily when subjected to pressure.

The lithological specimens gathered during the Horn Expedition included examples of a number of interesting rocks. The microscopical structure of some of the eruptive, and a few of the most typical of the metamorphic varieties, are briefly described by Mr. W. F. Smeeth and Mr. J. A. Watt, their paper being illustrated by four plates. The Palrontology of the expedition forms the subject of a separate contribution by Prof. Ralph Tate, who also deals with the botany.

\section{Origin of the Flora.}

The route traversed by the main body of the expedition practically circumscribes what has been termed the Larapintine region. The Larapintine flora is fully described, Prof. Tate taking in turn the general physiography and boundaries of the region, botanical characteristics, origin of the fora, previous explorations, enumeration of the flowering plants and vascular cryptogams, and diagnosis of new genus and species. The flora of the central "Eremian region" is briefly described in a separate paper.

The distribution of the constituent elements of the Larapintine flora and their exoteric relationships, taken in conjunction with the physiographic changes that have taken place within the area, lead to the conclusions that :-

(I) The Larapintine table-land was isolated, except perhaps in a northerly direction, during the deposition of the marine sediments constituting the Rolling Downs system (Upper Cretaceous).

(2) The marine submergence was replaced by a lacustrine area during the deposition of the Desert Sandstone (SupraCretaceous).

(3) A cosmopolitan flora prevailed at this period, which continued into Paleocene times.

(4) The area occupied by the lacustrine area of the Desert Sandstone period was somewhat reduced, yet high pluvial conditions continued into Pliocene times.

(5) In Post-Pliocene times a high state of desiccation was reached, which has continued till to-day. The cosmopolitan flora became largely extinct, and its place occupied by an Oriental immigration, more especially over the previously. submerged areas.

A short description, by Mr. J. H. Maiden, of the vegetable exudations collected during the expedition, concludes the volume.

We have had to content ourselves with a sketch of the work of the expedition and of the conclusions arrived at from the knowledge gained. This abridgment will suffice, however, to show the value of the results obtained in geology and botany; and we need only point to the volumes themselves as monuments to Mr. Horn's generosity, and to the industry of the members of the expedition organised by him.

NO. I 4 I 7, VOL. 55]

\section{UNIVERSITY AND EDUCATIONAL} INTELLIGENCE.

The Paris University Council has resolved to consider the institution of a degree which foreign students might take away with them as a proof of their studies and acquirements in Paris.

THE officers for the Oxford University Junior Scientific Club for next term will be as follows:--President: A. W. Brown (Christ Church). Treasurer : A. E. Boycott (Oriel). Editor : A. R. Wilson (Wadham). Chemical Secretary : W. P. Billinghurst (St. John's). Biological Secretary: J. E. H. Sawyer (Christ Church). Committee : R. A. Buddicom (Keble); E. H. Hunt (Balliol); D. Meinertzhagen (New Coll.).

AT the inauguration of the Lyons University, the Rector, $M$. Compayre, announced a donation to the university of $4000 /$. from M. Auguste Falcouz, a Lyons banker. The British Medical Tournal states that the interest of this sum is to be disposed of as follows :- Every two years a prize of $40 /$. sterling will be given to the students of each of the four faculties-literature, science, law, and medicine--who write the best essay on a current subject. The subject of the essay will be chosen by the Council of the Lyons University a year in advance. Every two years instruments for the science and medical faculties will also be bought. When fifty years have elapsed, the Lyons University will have entire control over the capital in order to be able to meet the demands of scientific progress.

DR. G. H. BRYAN, F.R.S., has been appointed professor of pure and applied mathematics in the University College of North Wales, at Bangor. Dr. Bryan graduated at Cambridge in I 886 as Fifth Wrangler. In I 888 he was Smith's Prizeman, his essay being published by the Royal Society; he was then elected Fellow of Peterhouse. In 1895 he became Fellow of the Royal Society, and received the degree of Doctor of Science of Cambridge University. Dr Bryan has been appointed one of the examiners for Part II. of the Mathematical Tripos (1897). $\mathrm{He}$ is the author of a valuable report to the British Association on the "Present State of our Knowledge of Thermodynamics," and of several other important papers on mathematics and mathematical physics.

Magdalen College, Oxford, has just elected Mr. R. W. T. Günther to an official fellowship as tutor in natural science. Mr. Ginther, who is the son of Dr. Albert Günther, F.R.S. so well and long known in the scientific world, has had a distinguished career at Oxford. He was elected to a demyship in natural science at Magdalen in 1888 , from University College School. He took a first class in morphology in 1892, was appointed University student of biology at Naples in 1893, and Royal Geographical student in 1895 , and has been first lecturer and then tutor at Magdalen since I894. He has made several contributions to Prof. Ray lankester's very interesting " Linacre Reports," and he read a paper at the British Association meeting last summer. It may be noted that Magdalen has already this term elected a demy and an exhibitioner in biology, the former coming from the Charterhouse. the latter being a pupil of Prof. Weldon at University College.

THE following are among recent announcements:-Dr. Surmont to be professor of hygiene at Lille; Dr. P. V. Lichtenfels to be full professor of mathematics in the Poly. technic Institute at Graz; Dr. Edler to be associate professor of agriculture in the University of Jena; Dr. E. Pringsheim to a professorship of physics in Berlin University; and Dr. Karl Friedheim to a professorship of chemistry; Dr. Kalischer to be professor of physics at the Technical High School of Berlin. Charlottenburg; Dr. Autenrieth, privat-docent of medical chemistry at Freiburg i. B., to be provisional successor to Prof. Baumanns ; Dr. J. Kurschak to be associate professor of mathematics at the Technical High School in Budapest; Dr. Anton Pestalozzi to be assistant in the Zürich Botanical Museum; Prof. Blass to be full professor of geology at Innsbruck. Dr. Szadeczky has been invited to become associate professor of geology at Klausenburg; and Prof. Allé, professor of mathematics in the German Technical High School at Prague, has been called to the Technical High School at Vienna.

THE conference of headmasters was opened at Rugby on Tuesday, and was largely attended. After a long discussion a resolution declaring the organisation of secondary education to be a matter of pressing necessity, with which the Government should be urged to deal in the next Session of Parliament, was carried, with a rider expressing the desire of the conference to 
co-operate with other educational bodies. In moving " That the new regulations for Woolwich examinations will not be satisfactory unless the number of subjects a candidate can take up is diminished by at least one, and that a heavy one, below the present number," the Rev. Dr. James said the Army curriculum afforded no education at all. It was, from the literary point of view, a failure, and from the scientific point of view was poor and inadequate. The incessant and irritating changes were a grave detriment to the intellectual development of the candidates. The result of these changes was especially felt in the department of science, and it was made impossible to give a really valuable scientific training. Under the old system nine was the maximum number of subjects. Now a boy was to be allowed to take up ten subjects, and the amount of mathematics in Class I. had been very largely increased, while a third alternative subject had been added which was beyond the reading required by the scholarship standard for mathematics at the Universities. Dr. James's resolution fell through, but the following were adopted in its place :-(I) That the new regulations for Woolwich examinations involve a disastrous increase of the burden of a curriculum which is already too heavy for candidates of the required age. (2) That it is not desirable that any such changes as are proposed should be made in regulations which have been only recently established, and which have enabled Woolwich and Sandhurst candidates to be generally prepared together, and that the committee be instructed to urge the views of the conference on the military authorities.

\section{SCIENTIFIC SERIALS}

American Journal of Science, December.-Archelon Ischyros, a new gigantic Cryptodire Testudinate from the Fort Pierre Cretaceous of South Dakota, by G. R. Wieland. This testudinate is closely allied to the genus Protostega. All the large bones were found in place, and the skeleton was almost complete. The ribs, which average $\mathrm{I} \mathrm{m}$. in length, are remarkable for their distal increase in thickness. The cervical centra are very heavy and strong bodies, and indicate a neck of enormous strength. The humerus measures $65 \mathrm{~m}$., the ulna $\cdot 33 \mathrm{~m}$., and the femur $46 \mathrm{~m}$. The total length is about II feet 4 inches, and the spread of the massive forearms 16 or 20 feet, this being the most striking feature of the animal. The skeleton was found embedded at the side of a small ravine near the South Fork of the Cheyenne River.-A method for the separation of aluminium from iron, by F. A. Gooch and F. S. Havens. The method is based upon the different solubilities of aluminium and ferric chlorides in strong hydrochloric acid. To test the method, measured portions of the standardised solution of aluminium chloride were evaporated nearly to dryness in a platinum dish, a measured amount of ferric chloride was added in a very little water, a mixture of equal proportions of ether and strong hydrochloric acid was introduced, the liquid was saturated at $15^{\circ}$ with gaseous hydrochloric acid, more ether was added to secure complete miscibility, and more gas passed to perfect saturation. The aluminium chloride was collected upon asbestos in a perforated crucible, washed with a mixture of ether and aqueous $\mathrm{HCl}$ thoroughly saturated with the gaseous acid, dried at $150^{\circ} \mathrm{C}$. for half an hour, covered with pure mercuric oxide, and igniter, gently at first, and finally over the blast. The error was less than I per cent.-Chemical composition of Hawaiian soils and of the rocks from which they have been derived, by A. B. Lyons. The relation in chemical composition of soils to the rocks from which they are derived can be most advantageously studied in a volcanic country, where disintegration of the rock is rapid and is attended with great chemical changes. In the Hawaiian soil there is observed a loss of more than half the silica, 77 per cent. of the manganese, 93 per cent. of the lime, gi per cent. of the magnesia, and about 50 per cent. of the phosphoric acid. It is especially interesting to note that while the rotted lava has lost nearly all its calcium and potassium, the soil retains a considerable proportion of both these elements, probably owing to the influence of plants and molluscous animals. - The Jurassic formation on the Atlantic coast, by O. C. Marsh. Adduce reasons why certain fresh-water formations in New Jersey and elsewhere along the Altantic coast should be regarded as Jurassic instead of Cretaceous.

Bulletin of the American Mathematical Socie'y, vol. iii No. 2, November. - The number opens with a report of the Buffalo Colloquium, a meeting which was held as auxiliary to the ummer meeting of the Society. It lasted a week, and the plan of it was that two courses of lectures should be given, consisting in each case of six one to two-hour lectures. Prof. Bôcher's subject was linear differential equations and their applications, and Prof. Pierpont's the Galois theory of equations. Outlines of the lectures are given. The result was so satisfactory that at the close of the Colloquium a motion was adopted recommending to the Council that arrangements be made for a similar gathering in connection with the next summer meeting of the Society.-A geometrical method for the treatment of uniform convergence and certain double limits, by Prof. Osgood, was read, as previously noted, at the summer meeting. It is a very thorough paper and fully illustrated. The geometrical representation of functions by curves and surfaces is, the author states, of twofold importance ; for not only does it represent to the eye, by means of a concrete picture, relations which would otherwise appear only in abstract arithmetic form, but this picture in its turn makes evident new facts, and points out at the same time the curve that the arithmetic proof of the theories thus suggested would naturally take.-Prof. Bôcher reviews Heffter's einleitung in die Theorie der linearen Differentialgleichungen mit einer unabhängigen variabeln. - From the notes we learn that Profs. Klein and J. J. Thomson addressed the Society on October 17.

Symons's Monthly Meteorological Magazine, December.Weather in the last century. Early records of the weather being somewhat rare, it was thought that summaries of the one in question were worthy of publication. The register was kept at Richmond by Mr. George Smith, a Proctor to Queen Anne, and contains a record of daily observations, made without instruments, from April I7 I3 to June I745. The original document is preserved in the library of the Royal Meteorological Society. - The scientific use of kites, by W. L. Moore, Chief of the U.S. Weather Bureau. The question discussed is simply, why kites are better than captive or unmanned balloons for exploring the upper air. The advantages over captive balloons are manifest. Prof. Moore has made out a strong case in favour of kites, but thinks that balloon observations should not be neglected. - Barometri descripizo, by J. Addison, 1672-1719. Attention has been called by Mr. Inwards, late President of the Royal Meteorological Society, to a poem under this title which is contained in Tickell's Addison, vol. vi. p. 427. The poem is reprinted in the current number of the Magazine, and the editor would be glad of a reference to any good translation that may exist

\section{SOCIETIES AND ACADEMIES.} LONDON.

Royal Society, December Io.- "The Chemical and Phy. siological Reactions of certain Synthesised Proteid-like Substances. Preliminary Communication." By Dr. John W. Pickering.

From the observations recorded in this paper it appears that if certain derivatives of proteids, and other substances of allied chemical constitution, are heated together in sealed tubes with an excess of either phosphorus pentachloride or pentoxide, a series of colloidal substances are formed which, when freed from the contaminating phosphoric acid, and dissolved in concentrated ammonia, give opalescent solutions that, on evaporation down in vacuo, yield substances closely resembling in physical, chemical, and physiological properties certain proteids.

These colloidal substances, although they differ from one another in minor details, are usually distinguished by the follow ing characteristics :-

(I) They are soluble in warm water, forming opalescent lævorotatory solutions.

(2) The resulting solutions yield the principal colour reactions hitherto deemed diagnostic of proteids.

(3) In the absence of salts, solutions of these colloids do not coagulate on heating. In the presence of a trace of a neutral salt they coagulate on heating at temperatures very similar to proteid solutions.

(4) Fractional heat coagulation shows the colloidal solutions are a mixture of different substances.

(5) The different constituents of the colloidal solution exhibil different physiological action.

(6) In the presence of an excess of neutral salts, or of salts of the heavy metals, the colloidal solutions behave in a manner similar to proteid solutions.

(7) When introduced into the circulation of pigmented 